\title{
ŠILDYMO POVEIKIS KELIO TIESIAMŲJŲ IR LENKIAMŲJŲ RAUMENŲ NUOVARGIUI IR ATSIGAVIMUI
}

\author{
Irina Ramanauskienė ${ }^{1,2}$, Albertas Skurvydas ${ }^{1}$, Marius Brazaitis ${ }^{1}$, Dalia Mickevičienè ${ }^{1}$, Mindaugas \\ Dubosas $^{1,2}$, Nerijus Masiulis ${ }^{1}$ \\ Lietuvos kūno kultūros akademija ${ }^{1}$, Kauno technologijos universitetas ${ }^{2}$, Kaunas, Lietuva
}

\begin{abstract}
Irina Ramanauskienè. Lietuvos kūno kultūros akademijos biomedicinos mokslų krypties doktorantė. Kauno technologijos universiteto Kūno kultūros ir sporto centro, Kūno kultūros katedros asistentė. Mokslinių tyrimų kryptis — raumenų fiziologija: temperatūros poveikis raumenų nuovargiui ir atsigavimui priklausomai nuo lyties ir fizinio krūvio.
\end{abstract}

\begin{abstract}
SANTRAUKA
Tyrimo tikslas - nustatyti, kaip šildymas veikia kelio tiesiamuju ir lenkiamuju raumenu nuovarge ir atsigavima. Tiriamos fiziškai aktyvios $(n=10)$ krepšininkès. Su jomis atlikome du eksperimentus skirtingai raumenu büsenai żvertinti. Tiriamosios buvo testuojamos Biodex Medical System — žmogaus kaulu ir raumenu testavimo bei reabilitacijos iranga, kai raumenys buvo iprastinès temperatūros ir pašildyti. Po 10 minučiu lengvo bègimo pramankštos buvo atliekama: kontrolinis testavimas prieš krüvi - (3 kartus tiesiant ir lenkiant koja per kelio sqnari fiksuotu $500^{\circ} / \mathrm{s}$ greičiu); praejjus 5 min — dinaminis krūvis (100 kojos tiesimu ir lenkimu per kelio sqnari fiksuotu $500^{\circ}$ / s greičiu); praejjus 10 ir 30 min po krūvio - kontrolinis testavimas pagal tq pati protokolq. Laktato koncentracija kraujyje nustatoma prieš fizini krūvi bei praèjus 5 ir 30 min po jo. Gauti rezultatai parodé, kad šildymas prieš dinamini krūvi sumažino kelio tiesiamuju raumenu jègq maksimaliosios jégos momentu per pirmq krūvio trečdali, taip pat sumažino ir kelio lenkiamuju raumenu atlikto darbo rodiklius. Raumenı šildymas prieš fizinį krūvì nepagreitino jų atsigavimo, tačiau padidino laktato koncentracija kraujyje.
\end{abstract}

Raktažodžiai: atliktas darbas, dinaminis krūvis, maksimaliosios jègos momentas, raumens nuovargis ir atsigavimas, raumenu šildymas.

\section{IVADAS}

$\mathrm{K}$ eičiantis aplinkos temperatūrai ar atliekant fizinį krūví, organizmo temperatūra kinta (Kay et al., 1999). Svarbus gyvo organizmo bruožas yra gebejjimas prisitaikyti prie kintančių aplinkos sąlygu (Enoka, 1994). Dauguma fiziologinių ir kitų organizme vykstančiu procesų yra glaudžiai susiję su kūno temperatūros pokyčiais (Bennett, 1984; Shellock and Prentince, 1985;
Bennett, 1990). Pakilusi kūno vidaus temperatūra greitina deguonies atsiskyrimą nuo hemoglobino ir mioglobino, metabolines reakcijas, aktyvina kraujo tèkmę raumenyse, mažina raumenų klampumą, didina veikimo potencialo sklidimo greiti, deguonies suvartojimą (Blomstrand et al., 1984; Shellock and Prentince, 1985; Febbraio et al., 1994; Booth et al., 2001). 
Yra žinoma, kad temperatūros pokytis santykiškai labiau veikia maksimaluji raumenu galingumą tų tiriamujų, kurie turi daugiau I tipo raumeninių skaidulų (Sargeant, 1987). Paradoksalu, kad atletai (sprinteriai, ieties metikai ir kt.), kuriems būtinas didelis raumenų galingumas, turi mažiausiai naudos iš raumenų pašildymo.

Ankstesni tyrimai parode, kad maksimalusis galingumas neabejotinai susijęs su raumens temperatūra (Davies et al., 1975; Asmussen et al., 1976) ir kad raumenų išugdomas greitis priklauso nuo temperatūros pokyčių (Sargeant, 1987).

C. J. de Ruiter ir A. de Haan (2000) nustatè, kad temperatūra veikia aktino ir miozino miofilamentų funkcija, todèl raumenų darbas labai priklauso nuo temperatūros pokyčių. Tokie rodikliai kaip maksimalioji izometrinė jèga, jẻgos greitis ir atsipalaidavimas (Mawdsley and Croft, 1982; Oksa and Rintamaki, 1995), taip pat galingumas (Oksa et al., 1996; Rome et al., 1984) sumažèja nukritus raumenų temperatūrai.

Yra žinoma, kad izokinetiniai pratimai plačiai taikomi kelio sąnario funkcijoms atsigauti, aplink ji esančių raumenų funkcijai gerinti bei testuoti. Izokinetiniu dinamometru galima ịvertinti sąnarių ir raumenų funkciją koją lenkiant per kelio sąnari fiksuotu greičiu.

Manome, kad raumens susitraukimo jèga priklauso nuo susitraukimo greičio, tipo ir raumens temperatūros - tai nustatoma tiriant kelio tiesiamujų ir lenkiamujų raumenų savybių kaitą maksimalaus izokinetinio krūvio metu, kai raumuo išugdo jëgą susitraukdamas ekscentriniu-koncentriniu režimu (koją lenkiant per kelio sąnarį fiksuotu $500 \%$ / s greičiu) ir po krūvio, kai raumens temperatūra yra padidejjusi.

Nepavyko rasti darbų, nagrinejjančių temperatūros poveikị žmogaus griaučių raumenims, esant dideliam raumenu susitraukimo greičiui. Todèl mūsų tyrimo tikslas - nustatyti, kaip šildymas veikia kelio tiesiamujų ir lenkiamujų raumenu nuovargi ir atsigavima, kai koja lenkiama per kelio sąnari fiksuotu $500{ }^{\circ} / \mathrm{s}$ greičiu.

Hipotezè — spejjame, kad prieš krūvị pašildytas raumuo pavargs greičiau, nei ịprastinès būsenos raumuo, kai yra atliekama 100 kojos tiesimu ir lenkimų fiksuotu 500 \% s greičiu.

Tyrimo naujumas - nustatème, kaip pasyvus šildymas veikia raumenų valingų judesių atlikimo efektyvumą, raumens nuovargi ir atsigavimą maksimalaus intensyvumo fizinio krūvio metu ir po jo.

\section{TYRIMO METODIKA}

Tiriamosios — fiziškai aktyvios $(\mathrm{n}=10)$ 1923 metų moterys (krepšininkès). Jos buvo supažindintos su vykdomo tyrimo tikslais, metodais, procedūra ir galimais nepatogumais. Norą dalyvauti tyrime jos patvirtino raštu. Tyrimas atliktas laikantis $1975 \mathrm{~m}$. Helsinkio deklaracijoje priimtų principų dèl žmonių eksperimentų etikos. Tyrimo protokolas aprobuotas KMU bioetikos komisijoje (Protokolo Nr. 80 / 2004).

Kelio tiesiamųjų ir lenkiamųjų raumenų savybių testavimo metodika. Tiriamosios buvo testuojamos „Biodex Medical System“ — žmogaus kaulų ir raumenų testavimo bei reabilitacijos aparatūra (Biodex Medical System 3).

Tyrimas atliktas Lietuvos kūno kultūros akademijos Žmogaus motorikos laboratorijoje. Tiriamosios po neintensyvios pramankštos - 10 min bègimo (pulso dažnis - 110130 tv. / min) - sodinamos i̇ „Biodex Medical System“ įrenginio kèdę, nustatoma visa kelio sąnario amplitudè (ištiesus ir sulenkus koją), kojos fiksuojamos per kelio sąnarį $90^{\circ} \mathrm{kampu}$, pasveriamos tada, kai jos fiksuotos $135^{\circ}$ kampu (1 pav.). Registravome tokius kinematinius rodiklius: raumenų jègą maksimaliosios jègos momentu ir atliktą darbą.

Raumenų pasyvaus šildymo metodika. Norèdami padidinti kelio tiesiamujų ir lenkiamuju raumenų temperatūra, tiriamujų kojas 45 minutėms panardinome į šiltą vonią, kurios vandens tempe-

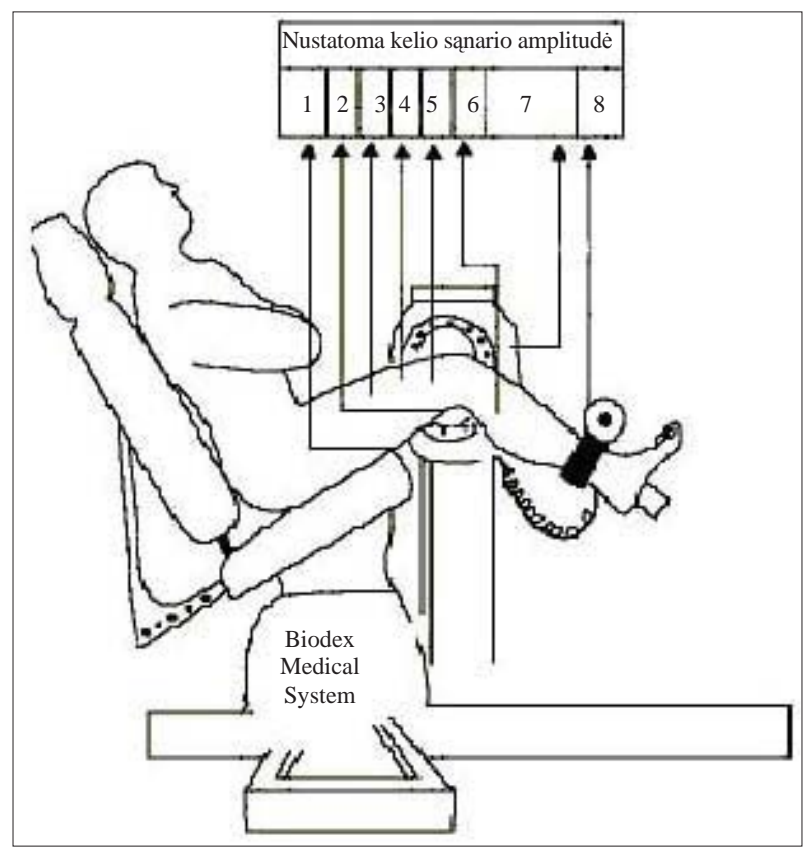

1 pav. Izokinetinio dinamometro veikimo schema 
ratūra buvo $44 \pm 0,1^{\circ} \mathrm{C}$. Remiantis A. J. Sargeant (1987) metodika, keturgalvio šlaunies raumens temperatūra $3 \mathrm{~cm}$ gylyje būna $38,9 \pm 0,3^{\circ} \mathrm{C}$. Tokiame raumens gylyje užregistruota temperatūra laikoma vidutine dirbančiu raumenų temperatūra (Blomstrand et al., 1984).

Laktato koncentracijos kraujyje nustatymo metodika. Laktato koncentracija kraujyje buvo nustatoma analizatoriumi Eksan-G (Kulis et al., 1988). Kapiliarinio kraujo mėginiai buvo imami iš piršto prieš krūvị ir praejjus 5 bei 30 min po jo. Analizatoriumi atliekamas fermentinių reakciju metu susidarančio vandenilio peroksido elektrocheminis tyrimas.

Tyrimo eiga. Iš viso atlikti du eksperimentai kai raumuo buvo iprastinès temperatūros ir pašildytas. Tarp tyrimų buvo ne mažesnè kaip mėnesio pertrauka. Eksperimentai vienas nuo kito skyrèsi tik tuo, kad antro metu tiriamuju, atliekančių dinaminio krūvio testa, raumenų temperatūra buvo padidinta $\sim 2,7^{\circ} \mathrm{C}$ (Saergeant, 1987). Visų eksperimentu eiga (kai raumuo buvo ịprastinès temperatūros ir pašildytas) ta pati. Tiriamosios prieš savaitę buvo supažindinamos su eksperimento eiga ir mokomos atlikti pratimą. Tyrimo metu jos galejjo vartoti gaiviuosius gèrimus. Kambario temperatūra viso tyrimo metu buvo pastovi $\left(20-22^{\circ} \mathrm{C}\right)$. Po $10 \mathrm{~min}$ lengvo bėgimo pramankštos buvo atliekama: kontrolinis testavimas prieš krūvi (3 kartus tiesiant ir lenkiant koją per kelio sąnarį fiksuotu 500 \% s greičiu); praejjus 5 min — dinaminis krūvis (100 kojos tiesimų ir lenkimų per kelio sąnari fiksuotu 500 \% s greičiu); praejjus 10 ir 30 min po krūvio - kontrolinis testavimas pagal tą pati protokolą. Laktato koncentracija kraujyje nustatoma prieš fizini krūvi bei praejus 5 ir 30 min po jo.

Statistiniai skaičiavimai. Apdorodami tyrimų duomenis, apskaičiavome aritmetini vidurki, standartini nuokrypi. Skirtumų tarp aritmetiniu vidurkių reikšmingumas buvo nustatomas pagal dvipusį nepriklausomų imčių Stjudento t kriterijų. Aritmetinių vidurkių skirtumo reikšmingumo lygmuo buvo laikomas svarbiu, kai paklaida mažesnè nei 5\% ( $<0,05)$. Skaičiavimus atlikome naudodamiesi statistiniais Microsoft ${ }^{\circledR}$ Excel 2000 ir SPSS paketais.

\section{REZULTATAI}

Tyrimo rezultatai parodè, kad raumenų susitraukimo jèga testavimo metu tiesiant koją sumažèjo 70\%, lenkiant — 67\% (2 pav.). Kelio tiesiamujų ir lenkiamųu raumenų jėga maksimaliosios jègos momentu statistiškai patikimai sumažèjo nuo antro kojos tiesimo ir atsigavo metu praèjus 10 minučiu po krūvio ( $<$ < 0,05) (2 pav.). Nustatėme, kad tiesiant koją per kelio sąnarį fiksuotu 500 / s greičiu, pašildyto raumens jèga maksimaliosios jègos momentu (nuo 9 iki 13, 19-23, 25-27, 31-34 ir 39-41 raumens susitraukimo), palyginti su ịprastinès būsenos raumens rodikliais, buvo reikšmingai mažesnè $(p<0,05)$, o nuo 41 raumens susitraukimo jègos reikšmingo skirtumo tarp testavimu nenustatėme $(\mathrm{p}>0,05)$ (2 A pav.). Palyginus šildyto ir iprastinès temperatūros raumens kelio lenkiamujų raumenų jègos maksimaliosios jëgos momentu, reikšmingas skirtumas aptiktas tik 18, 26, 56 raumens susitraukimo metu $(\mathrm{p}<0,05)$, tačiau didelio skirtumo nèra ( $>$ > 0,05) (2 B pav.).

Absoliučios reikšmès pateiktos lentelëje. Pašildytų kelio tiesiamujų ir lenkiamujų raumenų jèga maksimaliosios jègos momentu (100-ojo susitraukimo metu) sumažèjo (iprastinès temperatūros tiesiamuju raumenu — 44,60 $\pm 16,06 \mathrm{~N} \cdot \mathrm{m}$, pašildytų $-44,31 \pm 19,42 \mathrm{~N} \cdot \mathrm{m}$; iprastinès temperatūros lenkiamujų raumenu $-40,03 \pm 10,55 \mathrm{~N} \cdot \mathrm{m}$, pašildytų $-78,41 \pm 25,72 \mathrm{~N} \cdot \mathrm{m}(\mathrm{p}<0,05)$, lyginant su kontroline reikšme). Praejjus $10 \mathrm{mi}-$ nučių po dinaminio krūvio, kai kelio tiesiamieji raumenys buvo iprastinès temperatūros, išugdè $76,86 \pm 26,05 \mathrm{~N} \cdot \mathrm{m}$ jègą maksimaliosios jègos momentu, kai buvo pašildyti $-72,86 \pm 19,57 \mathrm{~N} \cdot \mathrm{m}$, kai kelio lenkiamieji raumenys buvo iprastinès temperatūros, išugde $78,41 \pm 25,72 \mathrm{~N} \cdot \mathrm{m}$ jèga, pašildyti $-75,81 \pm 33,25 \mathrm{~N} \cdot \mathrm{m}$ ir atsigavo iki pradinės (kontrolinės) reikšmès $(\mathrm{p}<0,05)$. Praejjus 30 min po krūvio šios reikšmès nekito (žr. lent.).

Testavimo metu nustatėme, kad raumenų atlikto darbo rodikliai tiesiant koją per kelio sąnarị sumažèjo $\sim 50 \%$, lenkiant — 60\%. Vertindami kelio tiesiamujų ir lenkiamųjų raumenų atliktą darbą nustatėme reikšmingą darbo sumažejimą nuo antro kojos tiesimo ir atsigavimo metu praejjus 10 min po krūvio ( $<$ 0,05) (3 pav.). Palyginus iprastinès temperatūros ir pašildytų kelio lenkiamujų raumenų atliktą darbą, nustatytas statistiškai patikimas rezultatu skirtumas atliekant 3-32-ą judesi ( $\mathrm{p}<0,05)$ (3 B pav.).

Kelio tiesiamujų ir lenkiamujų raumenų atliktas darbas (žr. lent.) sumažejo, kai jie buvo ịprastinès temperatūros ir pašildyti: iprastinès temperatūros tiesiamuju raumenu — 43,64 $\pm 15,64 \mathrm{~J}$, pašildytu $-45,47 \pm 16,26 \mathrm{~J}$, iprastinès temperatūros 


\begin{tabular}{|c|c|c|c|c|c|c|}
\hline \multirow{2}{*}{\multicolumn{3}{|c|}{ Atliktas krūvis }} & Prieš krūvị & $\begin{array}{l}\text { Iš karto po } \\
\text { krūvio }\end{array}$ & A 10 & A 30 \\
\hline & & & \multicolumn{4}{|c|}{ Jèga maksimaliosios jègos momentu, $\mathrm{N} \cdot \mathrm{m}\left(500^{\circ} / \mathrm{s}\right)(\bar{x} \pm \mathrm{SD})$} \\
\hline \multirow{2}{*}{ Tiesimas } & \multirow{9}{*}{ 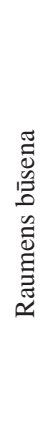 } & Iprastinès temp. & $77,32 \pm 23,61$ & $44,60 \pm 16,06^{*}$ & $76,86 \pm 26,05^{*}$ & $71,35 \pm 13,06$ \\
\hline & & Pašildytas & $74,12 \pm 12,61$ & $44,31 \pm 19,42^{*}$ & $72,86 \pm 19,57^{*}$ & $75,50 \pm 22,43$ \\
\hline \multirow{3}{*}{ Lenkimas } & & Iprastinès temp. & $72,64 \pm 24,48$ & $40,03 \pm 10,55^{*}$ & $78,41 \pm 25,72^{*}$ & $76,54 \pm 22,74$ \\
\hline & & Pašildytas & $69,23 \pm 18,97$ & $40,73 \pm 17,14^{*}$ & $75,81 \pm 33,25^{*}$ & $76,05 \pm 27,48$ \\
\hline & & & \multicolumn{4}{|c|}{ Atliktas darbas, $\mathrm{J}\left(500^{\circ} / \mathrm{s}\right)(\bar{x} \pm \mathrm{SD})$} \\
\hline \multirow{2}{*}{ Tiesimas } & & Iprastinès temp. & $112,03 \pm 38,23$ & $43,64 \pm 15,64^{*}$ & $122,32 \pm 31,95 *$ & $114,27 \pm 33,04$ \\
\hline & & Pašildytas & $105,57 \pm 27,37$ & $45,47 \pm 16,26^{*}$ & $120,01 \pm 28,98^{*}$ & $114,41 \pm 19,14$ \\
\hline \multirow{2}{*}{ Lenkimas } & & Iprastinès temp. & $85,84 \pm 25,66$ & $49,63 \pm 16,43^{*}$ & $95,36 \pm 35,82^{*}$ & $90,80 \pm 32,25$ \\
\hline & & Pašildytas & $71,80 \pm 19,53$ & $51,57 \pm 17,24^{*}$ & $96,67 \pm 48,15^{*}$ & $98,14 \pm 35,76$ \\
\hline
\end{tabular}

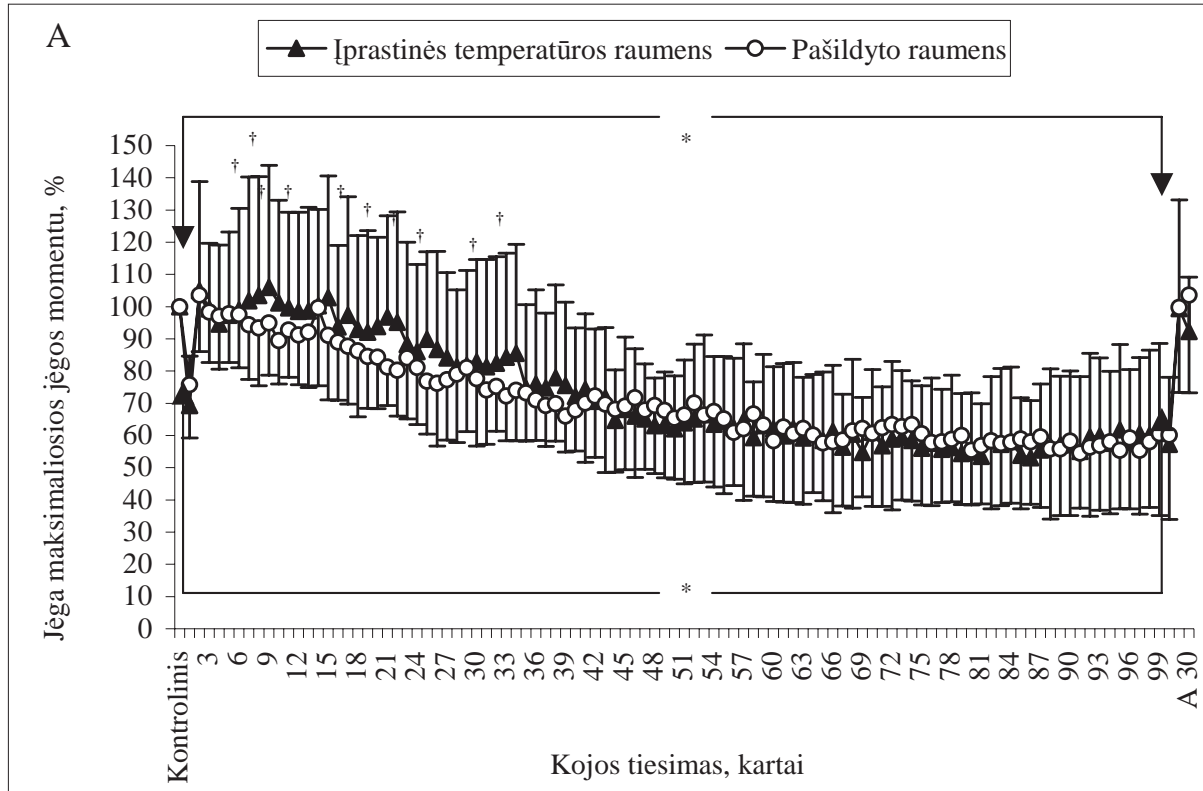

B

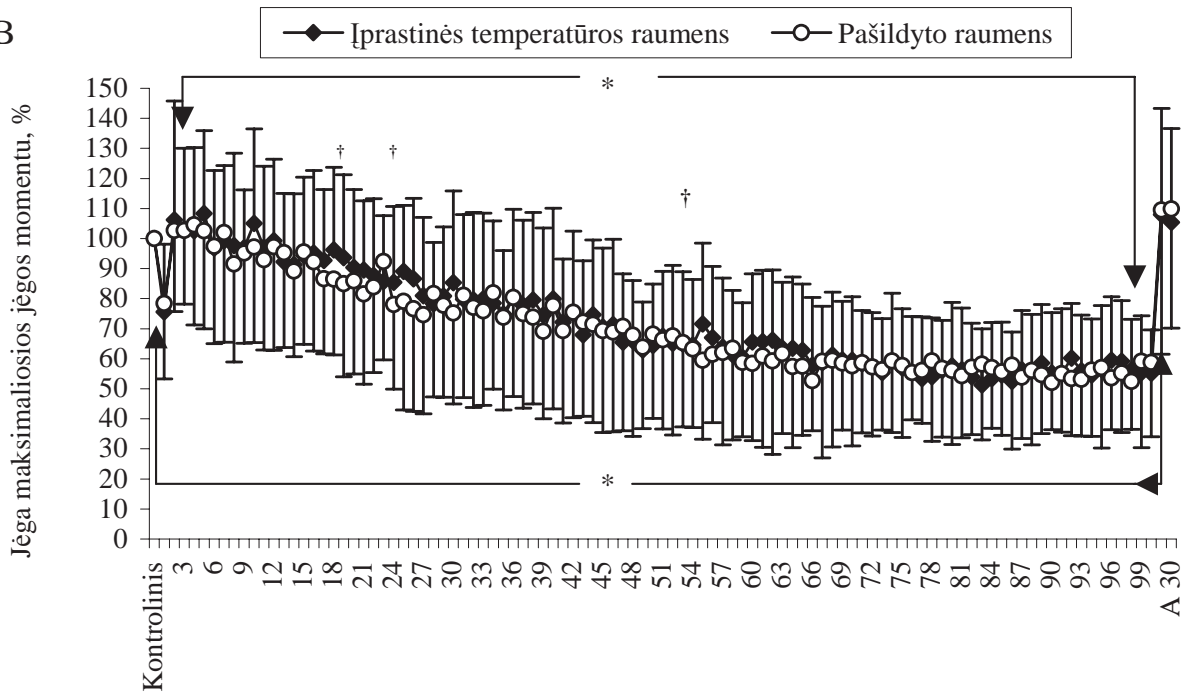

Kojos lenkimas, kartai
Lentelè. Maksimaliosios jègos ir atlikto darbo kaita dinaminio raumens susitraukimo metu

Pastaba. ${ }^{*}-\mathrm{p}<0,05$, maksimalioji jèga ir atliktas darbas reikšmingai pakito, lyginant su pradine (kontroline) reikšme.

2 pav. Jèga maksimaliosios jègos momentu (\%) atliekant dinaminị raumens susitraukimą (tiesiant (A) ir lenkiant (B) koją per kelio sąnari fiksuotu 500 \% s greičiu bei po krūvio praèjus 10 (A 10) ir 30 (A 30) min)
Pastaba. ${ }^{*}-\mathrm{p}<0,05-$ kelio tiesiamųjų ir lenkiamųjų raumenų jègos pokytis, lyginant su pradine (kontroline) reikšme. $\dagger-\mathrm{p}<0,05$ - iprastinès temperatūros ir pašildytų kelio tiesiamuju bei lenkiamuju raumenu jègos pokyčio skirtumas. lenkiamujų raumenų — 49,63 $\pm 16,43 \mathrm{~J}$, pašildytu - 51,57 $\pm 17,24 \mathrm{~J}(\mathrm{p}<0,05)$, lyginant su kontroline reikšme. Praejjus 10 minučiu po dinaminio krūvio, iprastinès temperatūros $(122,32 \pm 31,95 \mathrm{~J})$ ir pašildytų (120,01 \pm 28,98 J) kelio tiesiamujjų raumenu jėga atsigavo iki pradinès, lyginant su 
3 pav. Darbas, atliktas dinaminio raumens susitraukimo metu (tiesiant (A) ir lenkiant (B) koją per kelio sąnari fiksuotu $500 \%$ / s greičiu bei po krūvio praèjus 10 (A 10) ir 30 (A30) min)
Pastaba. ${ }^{*}-\mathrm{p}<0,05-$ kelio tiesiamųjų ir lenkiamųjų raumenu jègos pokytis, lyginant su pradine (kontroline) reikšme. $\dagger-\mathrm{p}<0,05-$ iprastinès temperatūros ir pašildytu kelio tiesiamųjų bei lenkiamųjų raumenu jègos pokyčio skirtumas.

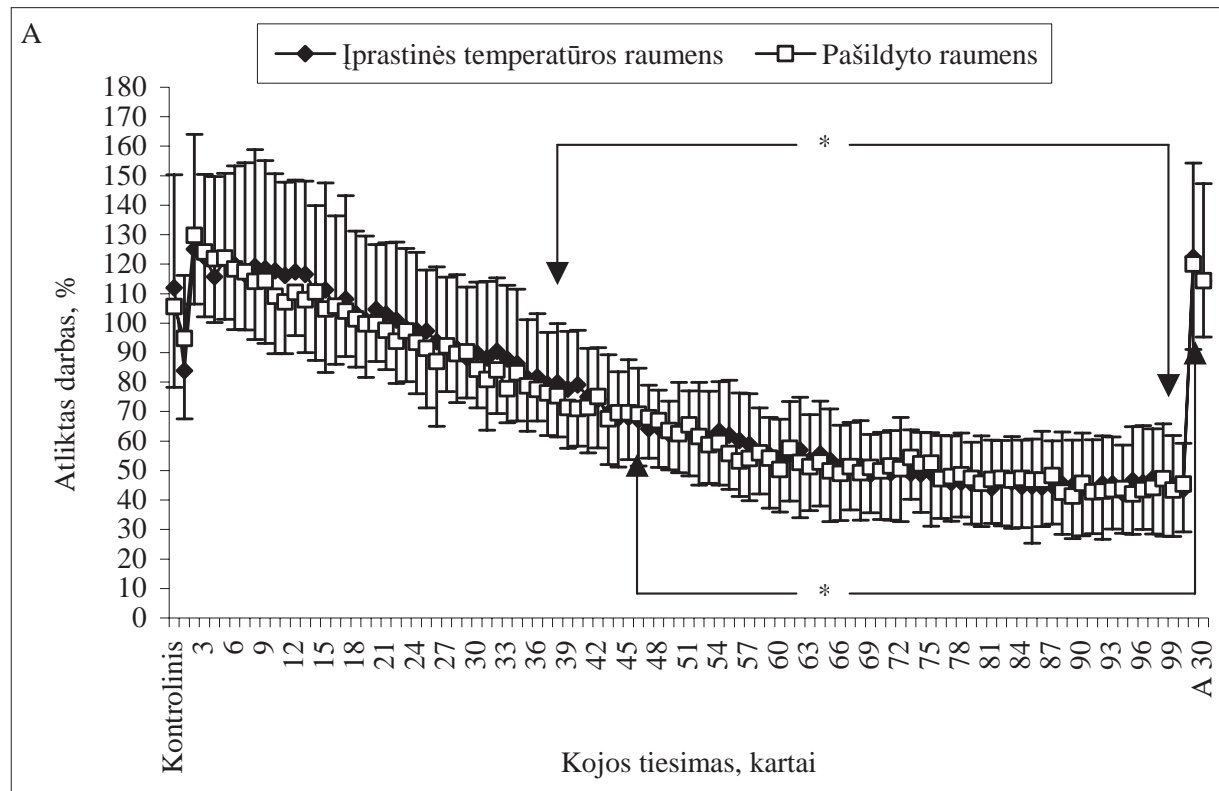

B

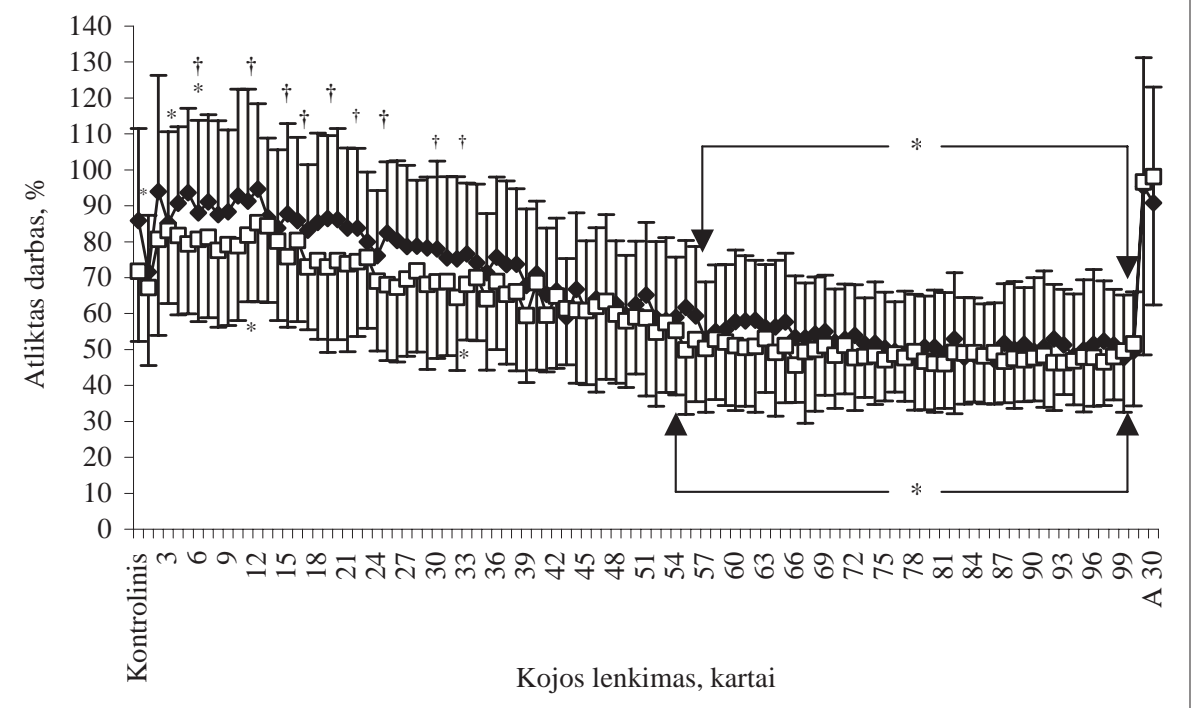

4 pav. Vidutinès laktato koncentracijos (La) kraujyje reikšmès prieš krūvị bei praẻjus 5 (A 5) ir 30 (A 30) min po jo

Pastaba. ${ }^{*}-\mathrm{p}<0,05$, La koncentracija kraujyje reikšmingai skiriasi, lyginant su pradine (prieš krūvi) reikšme. $\dagger-\mathrm{p}<0,05, \mathrm{La}$ koncentracija kraujyje reikšmingai skiriasi, kai raumuo buvo pašildytas ir îprastinès temperatūros.

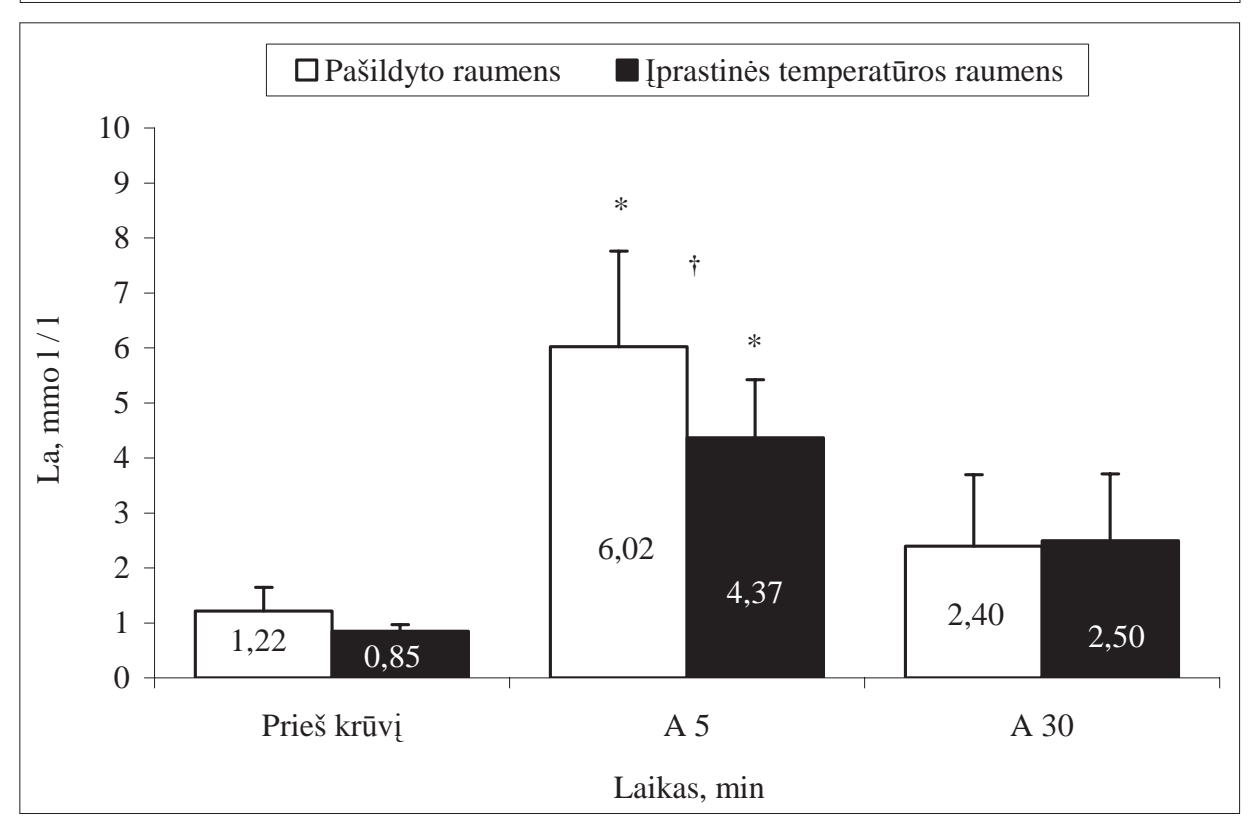


kontroline reikšme $(\mathrm{p}<0,05)$. Atitinkamai atsigavo kelio lenkiamujuc raumenu jëga: iprastinès temperatūros raumenų jèga buvo 95,36 \pm 35,82 J, pašildytų $-96,67 \pm 48,15 \mathrm{~J}$ (p $<0,05)$. Praejjus 30 minučiu po krūvio reikšmingo skirtumo, lyginant su pradine, nepastebèta (žr. lent.).

Praèjus 5 min po krūvio (A 5) laktato koncentracija kraujyje reikšmingai padidèjo, palyginti su kontroline reikšme $(\mathrm{p}<0,05)$. Praėjus 30 min šios reikšmės jau nesiskyrè. Lygindami įprastinės temperatūros ir pašildytų raumenų laktato koncentracijos kraujyje reikšmes, praejus 5 min po krūvio, aptikome statistiškai reikšmingą skirtumą $(\mathrm{p}<0,05)(4$ pav.).

\section{REZULTATŲ APTARIMAS}

Pagrindiniai tyrimo duomenys parodé, kad raumenų šildymas prieš fizinį krūvị nepagreitino ju atsigavimo, tačiau padidino laktato koncentraciją kraujyje.

M. A. Febbraio ir kt. $(1994,1996)$ nustatè, kad raumenyse ramybės metu energinių medžiagų ir jų skilimo produktų koncentracija normaliomis sąlygomis ir po šildymo nesiskiria. Atlikto tyrimo duomenys rodo, kad jègos maksimaliosios jėgos momentu ir atlikto darbo pradinès reikšmès nesiskiria nuo reikšmių, gautu po raumenų šildymo (žr. lent.).

Atlikto tyrimo rezultatai parode, kad skirtinga raumens temperatūra gali pakeisti jègos rodiklius. A. J. Sargeant (1987) teigia, kad jèga vidutiniškai gali padideti $4 \%$, kaskart didinant raumens temperatūrą $1^{\circ} \mathrm{C}$. D. C. Stanley ir kt. (1994) taikè toki pat šildymo metodą kaip A. J. Sargeant (1987), tačiau pašildžius raumenis jègos ir galingumo rodikliai, atliekant izokinetinius kelio tiesimo pratimus, nebuvo didesni. Eksperimento metu naudojome A. J. Sargeant (1987) metodika, tačiau mūsų tyrimo rezultatai parodé, kad šildymas prieš dinaminị krūvị sumažino kelio tiesiamujų raumenų jègą maksimaliosios jejgos momentu per pirmą krūvio trečdalị ir kelio lenkiamujų raumenu atlikto darbo rodiklius. Pasak M. A. Febbraio (2000), padidèjusi raumenų temperatūra susilpnina griaučių raumenų veiklą, medžiagų apykaita, ir tai sukelia nuovargi. B. Drust ir kt. (2005) nustatè, kad padidejjusi raumens temperatūra pagerina dinaminio krūvio kokybę, o darbo galingumas, kartojant dinamini krūvi, dèl hipertermijos taip pat sumažèja. Neatrodo, kad sumažèjęs krūvio atlikimo tempas būtų susijęs su metabolitų koncentracijos padidejjimu, todèl manoma, kad tai gali nutikti dèl padidejjusio branduolio temperatūros poveikio CNS funkcijai.

Kelio tiesiamujų raumenų jëgos maksimaliosios jejgos momentu sumažèjima, atliekant pirmą krūvio trečdalị, galima paaiškinti: aukšta kūno temperatūra reguliuoja CNS veiklą (Nielsen et al., 1997), taigi keliame hipotezę, kad hipertermijos pasekmès, jaučiamos atlikus pirmą krūvio trečdali, apsaugo raumens nuo šilumos smūgio ir jų pažeida (baltymų degradacija) (Jessen, 1987). Tačiau S. S. Cheung ir G. G. Sleivert (2004) irodè, kad atliekant dinamini kelio tiesimą (fiksuotu $240{ }^{\circ} / \mathrm{s}$ greičiu) jèga maksimaliosios jègos momentu nepasikeitè, tuomet kai branduolio temperatūra padidèjo iki $39,5^{\circ} \mathrm{C}$.

Manome, kad raumens funkcijos atsigavimas po dinaminio krūvio (100 kojos tiesimų ir lenkimų per kelio sąnari fiksuotu $500^{\circ} / \mathrm{s}$ greičiu) yra susiję su metaboliniu nuovargiu. Po krūvio raumenyse smarkiai sumažeja ATP ir kreatinfosfato, padidèja vandenilio jonų koncentracija (Inbar et al., 1996). Manoma, kad raumeninès skaidulos mioplazmoje padaugejja $\mathrm{Ca}^{2+}$, kurie vèliau lemia nuovargio atsiradimą (Westerblad et al., 1998).

Naujesni tyrimai pateikia daug smulkesnę informaciją ir nurodo, kad pakilus temperatūrai pagreitèja raumenu glikolizè, padidejja laktato gamyba, sumažèja kreatinfosfato lygis, padidèja kreatino kaupimasis (Febbraio et al., 1994; Ball et al., 1999). Nustatyta, kad praejjus $2-3 \mathrm{~min}$ po dinaminio krūvio, raumenyse normalizuojasi kreatinfosfato koncentracija, o po $10-15$ min vandenilio jonų koncentracija (Inbar et al., 1996). Gauti tyrimo rezultatai nerodo raumenų jègos maksimaliosios jègos momentu ir atlikto darbo rodiklių sumažèjimo praejjus 10 ir 30 minučiu po krūvio.

Gana sudètinga paaiškinti, koks yra raumenu šildymo poveikio mechanizmas ir kaip jis veikia raumenų atsigavimo kaitą. Viena iš aiškinimo krypčiu galètų būti siejama su karščio šoko sukeltų baltymų padidejjimu po šildymo ir krūvio.

Nustatyta, kad pasyviai pašildžius raumenis prieš dinamini krūvî, padidèjo laktato koncentracija kraujyje, palyginti su įprastinès temperatūros raumens rodikliais. Manoma, kad po raumenu šildymo atlikus fizinį krūvị dèl ankstyvesnio anaerobinio energijos gamybos būdo susidaro didesnè laktato koncentracija kraujyje (Febbraio et al., 1994, 1996). 


\section{IŠVADOS}

1. Šildymas prieš dinamini krūvị sumažino kelio tiesiamujų raumenų jẻgą maksimaliosios jègos momentu per pirmą krūvio trečdali, taip pat su- mažino kelio lenkiamujų raumenų atlikto darbo rodiklius.

2. Raumenų šildymas prieš fizinị krūvị nepagreitino jų atsigavimo, tačiau padidino laktato koncentraciją kraujyje.

\section{LITERATŪRA}

Asmussen, E., Bonde-Petersen, F., Jorgensen, K. (1976). Mechano elastic properties of human muscle at different temperatures. Acta Physiologica Scandinavica, 96, 83-93.

Ball, D., Burrows, C., Sargeant, A. J. (1999). Human power output during repeated sprint cycle exercise: The influence of thermal stress. European Journal of Applied Physiology, 79, 360-366.

Bennett, A. F. (1990). Thermal dependence of locomotor capacity. American Journal of Physiology, 259, R 253-258.

Bennett, A. F. (1984). Thermal dependence of muscle function. American Journal of Physiology, 247, R 217-229

Blomstrand, E., Bergh, U., Essen-Gustavsson, B. and Eklomb, B. (1984). Influence of low muscle temperature in human skeletal muscles. Acta Physiologica Scandinavica, 107, 33-37.

Blomstrand, E., Bergh, U., Essen-Gustavsson, B. and Eklomb, B. (1984). Influence of low muscle temperature on muscle metabolisme during intense dynamic exercise. Acta Physiologica Scandinavica, 120, 229-236.

Booth, J., Wilsmore, B. R., Macdonald, A. D. et al. (2001). Whole-body pre-cooling does not alter human muscle metabolism during sub-maximal exercise in the heat. European Journal of Applied Physiology, 84, 587-590.

Cheung, S. S. and Sleivert, G. G. (2004). Lowering of skin temperature decreases isokinetic maximal force production independent of core temperature. European Journal of Applied Physiology, 91, 723-728.

Davies, M., Ekblom, B., Berg, U., and Kastrup, I. L. (1975). The effect of hypothermia on submaximal and maximal work performance. Acta Physiologica Scandinavica, 95, 201-202.

Drust, B., Rasmussen, P., Mohr, M., Nielsen, B., Nybo, L. (2005). Elevations in core and muscle temperature impairs repested sprint performance. Acta Physiologica Scandinavica, 183, 181-190.

Enoka, R. M. (1994). Neuromachanical Basis of Kinesiology (pp. 273-283). Champaign, IL: Human Kinetic.

Febbraio, M. A., Carey, M. F., Snow, R. J., Stathis, C. G., Hargreaves, M. (1996). Influence of elevated muscle temperature on metabolism during intense, dynamic exercise. American Journal of Physiology, 271, 5 (Pt 2), R 1251-1255.

Febbraio, M. A. (2000). Does muscle function and metabolism affect exercise performance in the heat? Exercise and Sport Science Reviews, 28, 171-176.

Febbraio, M., Snow, R., Stathis, C., Hargreaves, M., Carey, M. (1994). Effect of heat stress on muscle energy metabolism during exercise. Journal of Applied
Physiology, 77, 2827-2831.

Inbar, O., Bar-Or, O., Skinner, J. S. (1996). The Wingate Anaerobic Test. Human Kinetics.

Jessen, C. (1987). Hipertermia and its effects on exercise perfomance. In J. R. S. Hales and D. A. B. Richards (Eds.), Heat Stress: Physical Exertion and Environment (pp. 241-249). Amsterdam.

Kay, D., Taffe, D. R., Marino, F. (1990). Whole-body pre-cooling and heat storage during self-paced cycling perfomance in warm humid conditions. Journal of Sport Science, 17, 937-944.

Mawdsley, R. H. and Croft, B. J. (1982). Effect of submaximal contractions before isokinetic testing. Athletic Training, Winter, 257-259.

Nielsen, B., Strange, S., Christensen, N. J., Warberg, J. and Saltin, B. (1997). Acute and adaptive responses in humans to exercise in warm humid environment. Pflugers Arch, 434, 49-56.

Oksa, J. and Rintamaki, H. (1995). Dynamic work in cold. Arctic Medicine, 54, 29-31.

Oksa, J., Rintamaki, H., Makinen, T., Martikala, V. and Rusko, H. (1996). EMG-activity and muscular performance of lower leg during stretch-shortening cycle after cooling. Acta Physiologica Scandinavica, 157, 71-78.

Rome, L. C., Loughna, P. T. and Goldspink, G. (1984). Muscle fiber activity in carp as a function of swimming speed and muscle temperature. American Journal of Physiology, 247, 272-279.

De Ruiter, C. J., De Haan, A. (2000). Temperature effect on the force-velocity relationship of the fresh and fatiqued human adductor pollicis muscle. Pflugers Arch, 440, 163-170.

Sargeant, A. J. (1987). Effect of muscle on leg extension force and short-term power output in humans. Journal of Applied Physiology, 56, 693-698.

Shellock, F. G. and Prentince, W. E. (1985). Warming-up and stretching for improved physical performance and preventation of sports-related injuries. Sports Medicine, 2, 267-278.

Skurvydas, A. (1998). Judesiu valdymo ir sporto fiziologijos konspektai. Metodinè priemonè. Kaunas: LKKI.

Stanley, D. C., Kraemer, W. J., Howard, R. L., Armstong, L. E., Maresh, C. M. (1994). The effect of hot water immersion on muscle strength. Journal of Strenght and Conditioning Research, 8, 134-138.

Westerblad, H., Allen, D. G., Bruton, J. D., Andrade, F. H., Lannergren, J. (1998). Mechanisms underlying the reduction of isometric force in skeletal muscle fatigue. Acta Physiologica Scandinavica, 162 (3), 253-260. 


\title{
EFFECT OF HEATING ON KNEE FLEXORS AND EXTENSORS DURING FATIGUING EXERCISE AND RECOVERY
}

\author{
Irina Ramanauskienė ${ }^{1,2}$, Albertas Skurvydas ${ }^{1}$, Marius Brazaitis ${ }^{1}$, Dalia Mickevičiené ${ }^{1}$, Mindaugas \\ Dubosas $^{1,2}$ Nerijus Masiulis ${ }^{1}$ \\ Lithuanian Academy of Physical Education ${ }^{1}$, Kaunas University of Technology ${ }^{2}$, Kaunas, Lithuania
}

\begin{abstract}
The aim of the present study was to establish the influence of muscle heating on knee-extensors and flexors, during fatiguing exercise and recovery. Ten female basketball athletes with no history of knee ligament injury performed two experiments on "Biodex System Pro 3" device. One hundred knee extensions / flexions with angular velocity of $500 \%$ s were obtained (first experiment) and the same dynamic exercise was repeated after the quadriceps muscle had been warmed (second experiment). Before (pre-exercise), ten minutes (post-exercise), and 30 min after the fatiguing exercise, three knee extensions / flexions with angular velocity of $500 \%$ s were performed. A blood lactate sample was taken before initial measurements and following exercise at 5 and 30 minutes. The evidence obtained in this study showed that, muscle heating before exercise decreased the peak torque of knee extensors during the first third part of exercise, likewise decreased volume of knee flexors work done. Muscle heating before the exercise had no effect on muscle recovery time, however increased a post-exercise blood lactate value.
\end{abstract}

Keywords: dynamic exercise, work done, peak torque, muscle fatigue, recovery, heating.

Gauta 2005 m. rugpjūčio 27 d.

Received on August 27, 2005

Priimta 2005 m. gruodžio 28 d.

Accepted on December 28, 2005

\author{
Irina Ramanauskienè \\ Lietuvos kūno kultūros akademija \\ (Lithuanian Academy of Physical Education) \\ Sporto g. 6, Lt-44221 Kaunas \\ Lietuva (Lithuania) \\ E-mail Irina.Ramanauskiene@ktu.lt
}

